FÁTIMA MOURA FERREIRA

\title{
O PORTUGAL DOS "ACÁCIOS": \\ O Conselheiro do Constitucionalismo Monárquico
}

Separata da Revista de História das Ideias, Vol. 28

Faculdade de Letras

Coimbra

2007 


\section{O PORTUGAL DOS "ACÁCIOS": O Conselheiro do Constitucionalismo Monárquíco}

\section{Literatura e cultura política liberal: o conselheiro queiroseano}

"Era alto, magro, vestido todo de preto, com o pescoço entalado num colarinho direito. [...] Fora, outrora, director geral do ministério do reino, e sempre que dizia - El-Rei! - erguia-se um pouco na cadeira. Os seus gestos eram medidos, mesmo a tomar rapé. Nunca usava palauras triviais. [...] Dizia sempre 'o nosso Garrett, o nosso Herculano'. Citava muito. Era autor. E sem familia, num terceiro andar na rua do Ferregial, amancebado com a criada, ocupava-se de economia política: tinha composto os Elementos genéricos da sciencia da riqueza e sua distribuição segundo os melhores autores, e como subtítulo: Leituras do serão!"

Eça de Queirós ${ }^{(1)}$

"IO Conselheirol representará, afinal, o tipo de qualquer sociedade, sem crítica interna?"

Borges de $\mathrm{Macedo}^{(2)}$

* Departamento de História, Universidade do Minho.

(1) Eça de Queiroz, O Primo Bazilio, Porto, Livraria Chardron de Lello \& Irmão, Lda., 1929, pp. 39-40.

(2) A. Borges de Macedo, "(O) Conselheiro em Eça de Queirós", in A. Campos Matos (org. e coord.), Dicionário de Eça de Queirós, $2^{\mathrm{a}}$ ed., Lisboa, Caminho, 1998, p. 232. 
O conselheiro, imortalizado por Eça escritor, ficou para a posteridade como sinónimo de convencionalidade balofa, mediocridade, ausência de coerência. Entre as criações eçianas é, plausivelmente, uma das que mais concorre para sugerir, no plano representacional, a visão depreciativa e unicolor que transcorre de Portugal sob o signo da Regeneração. Com efeito, ele encarna não apenas o incumprimento do ideal modernizador, perseguido e acalentado pelas gerações pretéritas, mas sobretudo a falacidade desse mesmo projecto, traduzido no simulacro do sistema representativo implementado, na esterilidade da luta político-partidária vigente, na ausência de grandeza das elites políticas e administrativas, incapazes de protagonizarem e gizarem a mudança, porque desprovidas de real sentido de Estado e apenas concentradas na mesquinhez dos egoísmos individuais ${ }^{(3)}$. Mas, se é certo que a responsabilidade maior é atribuída ao político - principal alvo do ataque queiroseano $0^{(4)}-$, o Conselheiro, na qualidade titular de que é investido representante honorífico do Constitucionalismo, converte-se em símbolo por excelência dessa mesma sociedade. Daí o estatuto particular que acabará por adquirir, entre o leque de tipos sociais que a ordem burguesa viu nascer e que o escritor caricaturou (o político, o burocrata, o homem de negócios, o bacharel, a jovem burguesa).

No espectro literário do autor, a relevância da personagem é indissociável do profundo impacto social que encerra, traduzido numa sintomatologia de vacuidade, tanto mais perniciosa, atendendo à disseminação lata do rotulado "espírito conselheiral". De onde o poder sugestivo da imagem, realçada por Borges de Macedo, entre outras formuladas pelo escritor, acerca de Portugal sob o signo da Regeneração: afinal, não era

(3) A síntese traçada tem por referente a etapa da obra do escritor encetada com O Crime do Padre Amaro e concluída com a publicação de Os Maias (1888). Sobre o sentido posterior da ficção do autor ver o ensaio de Augusto Santos Silva, "Eça de Queirós", Palavras para um País, Oeiras, Celta, 1997, pp. 120-140.

(4) Questionamos até que ponto o retrato cáustico traçado sobre o político, mormente em $O$ Conde de Abranhos, não redundará numa relativa diluição do potencial crítico que atravessa a percepção desse grupo. Explicitando: o registo caricatural é forçosamente deformador no sentido em que o empolamento de alguns dos seus traços, tidos por distintivos, potencia a sua própria representaçāo, na condição, afigura-se-nos, de ser respeitada uma tensão de credibilidade social com o objecto representado. 
apenas a capital, sede política, mas o país, no seu todo, que constituía uma "nação de conselheiros".

Evoquemos, em breves linhas, o retrato social do Conselheiro eçiano. Figura ubíqua, presente tanto em Lisboa como na província, o seu melhor representante, o Conselheiro Acácio (O Primo Basílio), corporiza ambiguamente os predicados da classe média, de matriz pequena burguesa. Austero, contido, dotado de porte e de linguagem de bom tom, ostenta uma trajectória social marcadamente ascendente - possibilitada pela pertença aos lugares de topo da hierarquia estatal, filiada nos princípios da meritocracia liberal -, partilhando, à sua escala e paralela distância, os símbolos da nova cultura.

No plano público, o Conselheiro afirma-se como agente da ordem político-administrativa regeneradora, não na qualidade de personagem de primeiro plano (lugar reservado ao político), mas antes como figura de retaguarda, garante da sustentabilidade e da durabilidade do regime, mormente da sua legitimação retórica. Afinal, não é ele, por norma, uma das peças da engrenagem administrativa, o burocrata ou outro quadro equivalente, personagem que partilha da hipocrisia que rege a ordem estatal, abrilhantando-a, no porte e na palavra, da mais solene gravidade e redundando, nesta ordem de ideias, num dos melhores produtos do Constitucionalismo ${ }^{(5)}$ ?

Dificilmente poderemos ver na tipificação da figura do "Acácio" um digno representante da burguesia. Diríamos, seguindo uma abordagem sociológica, que "[lhe] falta aquilo a que os burgueses chamam seriedade, essa capacidade que faz com que cada um seja o que é: forma social do princípio de identidade, que é a única a poder servir de fundamento a uma identidade social sem equívoco"(6). A fragilidade

(5) Além de Acácio, o representante mais ilustre, contam-se ainda na obra do escritor Pacheco e Vaz Neto ( $A$ Correspondência de Fradique Mendes); Sanches Lucena (A llustre Casa de Ramires); Pinto Porto (A Cidade e as Serras); Gama Torres (O Conde de Abranhos); Matos Miranda e José Matias (Contos), que constituem, no seu conjunto, explicitações do tipo social retratado por Eça. Ver, a este respeito, a sugestiva tipologia analítica fixada por Borges de Macedo acerca do respectivo universo in "(O) Conselheiro em Eça de Queiroz", ob. cit., pp. 231-232.

(6) Pierre Bourdieu, As Regras da Arte, Génese e Estrutura do Campo Literário, Lisboa, Editorial Presença, 1996, p. 31. 
da sua identidade social desagua, nestes termos, numa postura a que, dificilmente, é reconhecida competência, imagem da debilidade maior que perpassa a elite administrativa da Regeneração e que a converte num elemento de obstaculização permanente a todo e qualquer ensejo modernizador acalentado. O retrato de "Acácio" caminha a par com a percepção dominante traçada por Eça a respeito deste grupo social, imbuída de ambiguidade, de relativo pendor depreciativo e mesclado com um fino olhar elitista e irónico ${ }^{(7)}$ - como, aliás, se observa a respeito de outros segmentos sociais retratados pelo escritor, ainda que segundo outros ângulos de abordagem ${ }^{(8)}$. Mas a ambiguidade, em Eça, mais do que denotar a "real expressão" de uma determinada realidade sócio-histórica, constitui, como tem sido largamente sublinhado, parte integrante do artifício literário maior - a ironia - que o escritor manipulou magistralmente e que impregna o sentido da obra e do seu estilo singular.

(7) Retenha-se, a título meramente ilustrativo dessa ambiguidade, o retrato que o autor traça do jovem pequeno burguês modelo, eivado de sugestiva duplicidade: "[Jorge] fora sempre robusto, de hábitos viris. Tinha os dentes admiráveis de seu pai e os seus ombros fortes. § De sua mãe herdara a placidez, o génio manso. Quando era estudante da Politécnica, às 8 horas recolhia-se, acendia o seu candeeiro de latão. Abria os compêndios. Não frequentava botequins nem fazia noitadas. Só duas vezes por semana, regularmente, ia ver uma rapariguinha costureira, a Eufrásia [...]. Jorge achava-a romanesca e censurava-a. Ele nunca fora sentimental: os seus condiscípulos, que liam Alfred de Musset suspirando e desejando ter amado Margarida Gautier, chamavam-lhe proseirão, burguês. Jorge ria, não lhe faltava um botão nas camisas, era muito escarolado, admirava Luís Figuier, Bastiat e Castilho, tinha horror a dividas e sentia-se feliz." Eça de Queiroz, O Primo Bastlio, ob. cit,, pp.7-8. À semelhança do observado na retratação de outros segmentos sociais, assinale-se que o que é peculiar no escritor é a captação das incongruências que modelam o jogo social.

(8) Cf. Maria Filomena Mónica sobre a figuração da burguesia, aristocracia e outras fraç̧ões sociais na obra queiroseana Eça de Queirós, Lisboa, Quetzal Editores, 2001, pp. 135-151; 159-171; Isabel Pires de Lima a respeito de análoga problemática e, em particular, a análise produzida acerca dos artifícios literários eçianos, As Máscaras do Desengano, Para uma Abordagem Sociológica de "Os Maias" de Eça de Queirós, Lisboa, Editorial Caminho, 1987, respectivamente, pp. 144-164 e 227-246; e Mário de Sacramento, Ȩ̧a de Queirós - Uma Estética da Ironia, Lisboa, Editorial Presença, 1945, sobre os sentidos da ironia. 


\section{䊉}

Vale a pena explicitar a inclusão de Eça escritor no presente estudo, centrado na figura do Conselheiro oitocentista e que tem por fim traçar o seu perfil sociológico, no horizonte das representações dominantes dos símbolos distintivos da sociedade liberal e das respectivas práticas sociais, na vigência da ordem constitucional monárquica.

Porventura, para o nosso propósito, bastaria invocar o poder de imposição e de sedução do imaginário queiroseano e, sobretudo, o seu papel modelador na criação e veiculação de imagens literárias de matriz intelectual a respeito da sociedade e do país liberais, do último quartel de Oitocentos, por analogia com o potencial que outros registos discursivos encerram. Referimo-nos, concretamente, à capacidade que os discursos ideológicos e políticos têm para idearem e projectarem cenários sociais alternativos. De sublinhar, ainda, o discurso jornalístico, pelo efeito potenciador que realiza desses mesmos universos, re-criando-os - pela selecção que opera e pelo modo como os interpreta e apresenta - e difundindo-os a uma outra escala ${ }^{(9)}$. O mesmo equivale a relevar a imbricação que a literatura desenvolve com esses espaços

(9) Como o exemplifica o reconhecimento do poder do discurso jornalístico por Almeida Garrett, no contexto da primeira geração intelectual do liberalismo português - na condição de este se regular segundo uma matriz crítica e desapaixonada: "Em um Estado, e particularmente na época, em que se trata de estabelecer reformas e novas instituições, é utilíssimo um jornal que segundo o trilho da moderação, sem adular ninguém, sem deprimir a autoridade, sem censurar os depositários do poder por espírito de partidos, ou por vaidade ou alarde de engenho, pesa os objectos em si, mostra o mal onde existe, e inculca o bem que deve seguir-se. Não é nos tratados dos filósofos, que a maioria de uma nação aprende os seus direitos, os deveres políticos e morais, e os meios que deve valer-se para alcançar a maior soma de tranquilidade e de ventura. § A multidão não quer, nem quando quisesse teria tempo de ler tais obras, porém lê e pode meditar às vezes, quando desejosa de instruir-se, os pequenos e breves discursos de um periódico. Esta leitura não pode deixar de aproveitar-lhe, se nela se encerram verdades substanciais e ideias claras, que lhe iluminam o espírito obscurecido por uma educação desleixada". "Liberdade de Imprensa e ilustraçāo pública" (1827), Obras Completas de Almeida Garrett, Obra Política, Doutrinação da Sociedade Liberal (1824-1827), vol. VII, Lisboa, Editorial Estampa, p. 427. 
representacionais, não obstante as particularidades que a marcam e a distinguem ${ }^{(10)}$.

$O$ poder do discurso afigura-se, nesta ordem de ideias, elemento constitutivo da afirmação histórica da sociedade moderna, como ilustra, à sua escala, o período histórico que nos ocupa, particularmente expressivo desta realidade, mormente em termos da explanação tímida de uma ordem social animada e dinamizada pelo segmento das classes médias ${ }^{(11)}$. O mesmo equivale a afirmar, nas palavras de Alexandre Herculano, que "[o] que temos dito não é senão o resumo do pensar do nosso século, pensar que ele tem revelado em doutrinas e em obras, porque o carácter que o distingue de todos os outros é o ter ajuntado o reflectir ao obrar, o ser cogitador ao ser activo" ${ }^{\prime \prime(12)}$.

E no esteio analítico em que nos situamos, afigura-se, pela sua pertinência heurística, ser importante assinalar a abordagem que Pierre Rosanvallon fez sobre o "liberálismo como cultura e não como uma doutrina" e, a partir deste ângulo, "compreender a formação e a evolução das racionalidades políticas $e$ sociais, ou seja, dos sistemas de representação que comandam o modo como uma época, um país ou grupos sociais conduzem a sua acção e perspectivam o seu futuro. Partindo da ideia que estas representações não são um invólucro exterior à consciência dos actores - como são por exemplo as mentalidades -, mas que elas resultam, pelo contrário, de um trabalho permanente de reflexão da sociedade sobre ela própria"(13).

${ }^{(10)}$ De entre a vasta bibliografia sobre o tema, limitamo-nos a sugerir a abordagem inscrita em Claude Lefort, El arte de escribir y lo politico, Barcelona, Herder Editorial, 2007, acerca do poder da linguagem e do pensamento.

(11) Ver, designadamente, José-Augusto França, O Romantismo em Portugal, Estudo de Factos Socioculturais, Lisboa, Livros Horizonte, 1993, em particular "A Palavra em Liberdade", pp. 165-173.

(12) In Alexandre Herculano, "Notícia Jurídica dos Nobres em Portugal", Joel Serrão (org.), Opúsculos, tomo II, Livraria Bertrand, 1984, p. 305.

(13) Pierre Rosanvallon, Le libéralisme économique, Histoire de l'idée de marché, Éditions du Seuil, 1989, pp. VIII-IX (tradução nossa). Para uma explanação dessa abordagem ver, do mesmo autor, L'État en France de 1789 à nos jours, Éditions du Seuil, 1990, em particular, cap. II ("L'Instituer du Social", pp. 95-127) e Le Modèle Politique Français, La société civile contre le jacobinisme de 1798 à nos jours, Éditions du Seuil, 2004. 
A exemplaridade de Eça escritor não deve, contudo, obscurecer o lugar que a literatura ocupa no horizonte da matriz e da tradição da cultura política liberal oitocentista ${ }^{(14)}$, patenteada na estreita vinculação registada entre o Romantismo e o Liberalismo, no contexto nacional ${ }^{(15)}$.

Limitemo-nos a evocar, em face dos propósitos analíticos perseguidos neste texto, os representantes mais emblemáticos dessa cultura política de recorte romântico-liberal, Herculano e Garrett, fixando-nos em alguns dos vectores que a perpassam.

Em paralelo ao ímpeto doutrinal que transcorre de uma ideação nuclear acerca de uma sociedade fundada nas classes médias - aspiração que traduz a dupla intenção de promover a reconciliação entre o passado e o futuro e, em simultâneo, a corporização, a breve trecho, de uma ordem social consonante com a orgânica política implementada -, o que se nos figura de relevar é o ideal forjado sobre o protagonista dos novos tempos, daquele que tem por missão levar a cabo a materialização do projecto modernizador.

Encontramos em Alexandre Herçulano uma das expressões mais cabais do pensamento societário liberal português (em paralelo a Vicente Ferrer) traduzida na assunção do individualismo inscrito numa matriz de desigualdade e que encontra na ideação da aristocracia, mais de mérito do que de sangue, uma das suas corporizações. Nas palavrạs do historiador, esta consubstancia-se em termos de "manifestação indestrutível da desigualdade" social e na "regra da superioridade individual", não radicada "[na] forma porque adquiriu os valores", já que o importante "é que actualmente os possua: que exista um facto

${ }^{(14)} \mathrm{Cf}$. o conceito de cultura política e sua tradução no quadro do Liberalismo, numa óptica francesa, em Nicolas Roussellier, "La culture politique libérale", Serge Berstein (dir.), Les Cultures Politiques en France, Éditions du Seuil, 1999, respectivamente, pp. 69-112, em especial 69-80.

(15) Para o desenvolvimento deste ponto ver Fernando Catroga, Paulo Archer de Carvalho, "Os Intelectuais na nova sociedade liberal"; "Almeida Garrett e o romantismo", "Herculano e o romantismo liberal", in Sociedade e Cultura Portuguesas II, Lisboa, Universidade Aberta, 1996, respectivamente, pp. 35-38, 43-56, 63-76; Fernando Catroga, "Ética e Sociocracia. O exemplo de Herculano na Geração de 70", in Studium Generale, n 4, 1982; Maria de Lourdes Costa Lima dos Santos, Intelectuais Portugueses na Primeirn Metade de Oitocentos, Lisboa, Presença, 1988; João Medina, Herculano e a Geração de 70, Lisboa, Terra Livre, 1977. 
que a força bruta pode destruir, mas que a razão pública não pode deixar de reconhecer" ${ }^{\prime \prime}(16)$.

A radicalidade que transparece na ideação de Herculano sobre a aristocracia encontra o seu fundamento último no cristianismo, substrato que permeia e modela o pensamento liberal do autor e que dá corpo ao ideal sociabilitário por ele preconizado. Seja como for, as fontes legítimas da afirmação social encontram-se identificadas e equiparadas: o trabalho e o mérito intelectual, que concorrem em prol da concretização das esperanças de mobilidade alimentadas pelas classes médias.

A concepção societária de Herculano, registada num enunciado de matriz evocativa, não deixou de surtir eco nos protagonistas da Geração Nova, como os próprios o reconheceram.

É certo que Antero, a par com Oliveira Martins, acentuou o carácter interclassista da "classe média" - idealizando-a como a agregação dos pequenos proprietários, dos pequenos industriais e a seu modo do proletariado - e acalentando, assim, o propósito de esta se expandir como elemento activo e reformador, transmutando-se na "universalização da burguesia, consolidada com instituições permanentes: ora não é este o sonho doirado do burguessísmo Herculano?"(17)

A distância maior dos representantes da Geração Nova relativamente ao escritor de Vale de Lobos radica na rejeição do atomismo social em nome de um organicismo que actuaria como força motriz, permitindo ultrapassar as incongruências sociais e políticas do liberalismo, pondo termo ao decadentismo instaurado em Portugal.

Críticos da ideologia do regime e da sociedade burguesa implementada, o horizonte doutrinal da Geração Nova corporizou-se num leque de movimentos ideológicos e culturais vasto - socialismo, republicanismo, positivismo, cientismo, sociologismo, realismo e naturalismo - que, no seu conjunto, independentemente dos enfoques particulares, denota uma aspiração e uma crença comum: a de promover uma compreensão objectiva e crítica da realidade e, através dela, influir e intervir, segundo cambiantes de acção diversas, na mudança qualitativa do mundo social, corporizando a "ideia nova". Em simultâneo, também elegeram um

(16) "Abolição dos Vínculos", in Jorge Custódio, José Manuel Garcia (org.), Opúsculos II, Lisboa, Presença, 1983, pp. 42.

(17) In Fernando Catroga, "A 'Questão Social' e a 'Questão Política'", in Antero de Quental, história, socialismo, política, Lisboa, Editorial Notícias, 2001, p. 178 
adversário comum: o liberalismo (político e económico) e a sua versão como Monarquia Constitucional. Versão que, mesmo quando filantrópica em relação aos desfavorecidos, não deixava de ser feita na óptica de uma certa aristocracia de mérito, na época encarnada na figura do escritor.

É nesta matriz que se inscreve Eça. Ela permeia a sua obra, como o evidenciam as referências a Proudhon, Taine, entre outros, intervindo como ferramenta no delineamento dos personagens e na reçonstituição dos respectivos universos sociais. Mas o seu fim é, fundamentalmente, estético. Acresce, a relevância do olhar social de Eça, inscrito no segmento da alta burguesia intelectualizada, de pendor aristocratizante, que condiciona e molda, de forma expressiva, a sua percepção dos ambientes sociais - vertente denunciadora do carácter infrutífero de todo o exercício analítico que tenha por fim apreender o grau de verosimilhança dos cenários sociais descritos subjectivamente pelo escritor, ainda que registados sob a capa formal e estilística dos cânones (ideológicos) do realismo ${ }^{(18)}$. É, justamente, pela sua capacidade magistral de exprimir visões particulares sobre o modo (plural) de percepcionar e de representar o mundo social que se justifica, em parte, esta digressão analítica, tanto mais significativa em função do nosso propósito: captar imagens, valores e sentidos alternativos àqueles que se impuseram como dominantes e que se difundiram, segundo ritmos e escalas diferenciadas, sobre a sociedade, mediante apropriações várias.

É certo - como tem sido, aliás, devidamente relevado - que Eça escritor não se afirmou como intelectual crítico (pese embora a aparente redundância) ou reformador social, no contexto da sua obra literária -; o que não invalida as facetas de crítica social que a povoam, ou, num outro sentido, as aspirações de teor intelectualizante que alimentou realizar e concretizar $^{(19)}$. Muito provavelmente, porque não o pretendeu ser. Antes se assumiu, sobretudo, como criador e artista, como o sugerem, de forma bem explícita, alguns dos excertos que nos legou - no âmbito de um eventual propósito auto-representacional que o autor acalentou em termos de contributo no processo de elaboração da sua imagem

${ }^{(18)}$ Cf. Helder Macedo, "Garrett no Romantismo Europeu", Trinta Leituras, Lisboa, Editorial Presença, 2007, em especial pp. 28-29 sobre os artifícios literários que subjazem à construção da suposta neutralidade preconizada pelo realismo.

(19) Fernando Catroga, ob. cit., p. 178. 
póstuma ${ }^{(20)}$ - e que denotam a assunção do poder distintivo da arte relativamente a outros domínios consagrados da actividade social, concretamente a política e a religião.

"A arte é tudo porque só ela tem duração - e tudo o resto é nada! As Sociedades, os impérios são varridos da terra, com os seus costumes, as suas glórias, as suas riquezas [...]. Só um livro é capaz de fazer a eternidade de um povo. Leónidas ou Péricles não bastariam para que a velha Grécia ainda vivesse, nova e radiosa, nos nossos espíritos: foi-lhe preciso ter Aristófanes e Esquilo. Tudo é efémero e oco nas Sociedades - sobretudo o que nelas mais nos deslumbra"(21).

Sob análogo diapasão se inscrevem as palavras de Antero, registadas a pretexto da publicação da terceira versão do Crime do Padre Amaro, emblemáticas do reconhecimento do perfil de criador e da atitude que o diferencia e o distingue em termos da afirmação de uma identidade artística singular:

"Há muito tempo que não leio coisa que me dê tanto gosto e o que é melhor, que me fizesse pensar. O seu livro é o melhor exemplar de psicologia social portuguesa contemporânea [...]. Dir-lhe-ei somente. que V. adquiriu finalmente a segurança, a facilidade e aquela espécie de bonomia superior, que é própria dos mestres. Está já acima das escolas; aquilo não é realismo, nem naturalismo, nem Balzac, nem Zola: aquilo é a verdade, a natureza humana, que é o que faz as obras sólidas, não os sistemas ou as escolas. [...] Agora está V. na região serena da contemplação pura das coịsas, cheio de longanimidade, imparcial, vendo só os homens e os corações dos homens, pelo interesse que neles há, pela verdade natural, e não como argumentos para teses. Isto, quanto a mim, é que é o verdadeiro realismo, verdadeiro naturalismo, isto é que é a grande Arte. Assim fizeram Molière e Shakespeare, Balzac e Goldsmith. O seu livro deixou de ser uma obra de tendências para ser

${ }^{(20)}$ Designadamente no âmbito de projectos editoriais que alimentou como o testemunha a Revista de Portugal.

(21) Eça de Queiroz, "Prefácio dos Azulejos do Conde de Arnoso", in Beatriz Berrini, Eça de Queiroz Literatura e Arte. Uma antologia, Lisboa, Relógio d’Água, 2000, pp. 72-73. 
uma obra humana. A longanimidade, a indiferença inteligente com que V. descreve aquela pobre gente e os seus casos, encantou-me.[...] [P]or isso a Arte é sempre serena, tolerante, magnânima".

Indo ao encontro do escritor: "o estilo é uma forma de pensamento". O que equivale a sustentar que a singularidade de Eça radica, primeiramente, na dimensão estética que impregna a sua obra e perpassa o seu olhar sobre a sociedade da Regeneração, não obstante as leituras múltiplas que ela possibilita em função do perfil do leitor e dos ângulos de abordagem que autoriza.

Talvez aí resida uma das fontes magistrais do imaginário queiroseano pela plasticidade que o corporiza. Admite-se que o impacto dos conteúdos e das imagens formuladas acerca da "Galeria de Portugal do Século XIX" constituíram uma rẹferência viva entre as fracções intelectualizadas suas contemporâneas, ainda que assumindo sentidos potencialmente divergentes. O poder encantatório de Eça, já então e para a posteridade, terá assentado na postura distanciada, crítica e desencantada que magistralmente explanou na sua obra, mediante a manipulação exemplar da ironia e do jogo de contrários, artifícios estilísticos maiores entre outros a que recorreu ${ }^{(22)}$. Também aí residirá o poder de ilusão de Eça: fazer parecer que o registo literário se afigura ao do intelectual - pois só o distanciamento crítico (tido por marca suprema distintiva do segundo) possibilita a apreensão da verdade - ainda que tão-somente corresponda à criação de um espaço propício ao desenvolvimento de "afinidades electivas"(23).

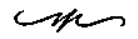

Certamente, encontraremos ressonâncias do Conselheiro queiroseano na análise que traçamos sobre o. Conselheiro do Constitucionalismo. Estas encontram eco, designadamente, nos olhares displicentes daqueles, por vezes anteriores a Eça, que ironizam acerca dos símbolos sociais que decoram a ordem social pela sua futilidade e vaidade social.

${ }^{(22)}$ Sobre o potencial argumentativo das figuras estilísticas no âmbito dos discursos historiográfico e sociológico ver, designadamente, Dominick LaCrapa, "Rethinking Intellectual History and Reading Texts", History and Theory, $\mathrm{n}^{\circ} 19$, 1980, pp. 245-276; Richard Brown, Clefs pour une poétique de la sociologie, Arles, Act Sud, 1983.

${ }^{(23)}$ Goethe, As Afinidades Electivas - Um Romance, Lisboa, Relógio D’Água, 1999. 
Ou ainda, no olhar distintivo de outros que, ancorados nas fontes reactualizadas de prestígio social - intelectual, político, cultural-podem partilhar de uma análoga visão do mundo crítica e supostamente superior à imperante, alimentando desígnios potencialmente alternativos.

Mas o poder de modelação da realidade social impõe-se. E traduz-se nas diversidades dos sentidos que perpassam as práticas sociais, sejam elas consonantes ou divergentes face aos cânones dominantes. Em simultâneo, a dinamização das práticas decorre, em larga medida, do grau de receptividade conferida ao novo face ao velho, binómio no qual as representações de matriz ideológica desempenham um papel fundador e legitimador, pese embora as roupagens ulteriores que estas venham a revestir em termos da realidade social.

A análise que iremos apresentar sobre o Conselheiro no (e do) Constitucionalismo ilustra, como veremos, essa tensão, a partir de um estudo que se inscreve num recorte temporal vasto (entre 1834 a 1910), e que foi atravessado por configurações políticas e ideológicas particulares, modeladoras, à sua escala, dos valores sociais que se repercutiram, mesmo em diferido, nos perfis sociais dos Conselheiros oitocentistas. Mas, talvez, também ela possa contribuir para um olhar cruzado entre as várias representações, neste caso, as da literatura e as da historiografia, perspectiva que, porém, não pretende sacralizar esta última, embora tenha a intenção de relativizar a primeira. Por outras palavras: se Eça sabia o que era um Conselheiro, sabê-lo-ão os seus leitores? E; comummente, não tomarão estes, em termos sociológicos, a parte pelo todo?

\section{A concessão da graça: a entrada no universo dos Conselheiros}

"Agradeço a graça que devo à benevolência da soberana e dos ministros, da qual não tive prévio conhecimento, mas o modo como eu entendo os deveres da honra politica [...] obrigal-me] a suplicar a Sua Majestade que me permita não aceitar a recompensa com que se dignou galardoar a minha fidelidade ao serviço do tronoe da Nação, e na qual espero em Deus que hei-de permanecer invariavelmente".

(Requerimento de renúncia, datado de 9-7-1851, à mercê do título de Conselho outorgado por decreto de 3 de Junho de 1851) $)^{(24)}$.

(24) ANTT, Ministério do Reino, Série Decretos, NT $1302 \mathrm{n}^{\circ}$ prov. José Inácio Pereira Derramado. 
"Atendendo aos relevantes serviços que tem evidenciado, num largo periodo de tempo, como secretário da Administração dos Caminhos-de-ferro do Estado, com 'uma competência e um zelo notáveis, e mais ainda todos os primores de inteligência e de carácter necessários à acção profissional e social do homem moderno' $[$...], qualidades postas em prova na dificil comissão que o levou a Londres mando lavrar o decreto de concessão do título de conselho".

(Ofício do Ministro das Obras Públicas sobre decreto de ñomeação de Conselheiro, datado de 4 de Julho de 1907 e fixado a 9 do mesmo mês) ${ }^{(25)}$.

Afinal, o que significava ser Conselheiro na sociedade oitocentista? Os diplomas acima transcritos, distanciados mais de meio século, evidenciam duas concepções distintas sobre o valor atribuído à nomeação de Conselheiro de sua Majestade. À sua escala, podem servir de ilustração sobre os significados divergentes reconhecidos socialmente aos símbolos honoríficos, desde os alvores do regime Constitucional Monárquico até ao seu desfecho. Em paralelo, sugerem expressões diferenciadas sobre o modo como a tradição é encarada em termos de dinâmica social.

Plausivelmente, o diploma mais representativo, em termos da sua adequação às expectativas alimentadas por fraç̧ões das "classes médias" - abstraindo, em parte, a capital pela irradiação crescente da ideologia republicana, então em curso - é o referente aos alvores de 1900, no qual a concessão do título de Conselheiro se configura como parte integrante do perfil social do homem moderno, no caso presente, um engenheiro dos Caminhos-de-Ferro do Estado. A modernidade casa-se bem, na óptica do responsável pela pasta das Obras Públicas, com o valor da distinção filiado na tradição.

Em contraponto, o diploma de 1851, referente à assunção formal de renúncia a um título honorífico, porque contrário aos valores do individualismo liberal, traduz um gesto marginal, que encontra as suas raízes na atitude adoptada por alguns notáveis liberais, no passado, que, analogamente, recusaram ofertas de títulos nobiliárquicos, em sinal da afirmação distintiva das suas origens plebeias e do novo

${ }^{(25)}$ ANTT, Ministério do Reino, Série Decretos mç. 129, cx. 140, José Fernando de Sousa. 
sentido de serviço público, atitudes consonantes com os valores da ideologia professada ${ }^{(26)}$.

É certo que a memória representacional sobre as ideações da nova sociedade a erguer, largamente associada ao património vintista, enformada segundo os valores concebidos como próprios das classes médias em oposição aos da aristocracia do Antigo Regime, se conservou através da imprensa, ainda que de forma diluída e esparsa ${ }^{(27)}$. Sobretudo na qualidade de referência a um passado de autenticidade (mitificada), por contraponto à sociedade firmada, demasiado presa ao fascínio dos símbolos honoríficos ${ }^{(28)}$. Mas ela coexiste com o elogio e a divulgação

${ }^{(26)} \mathrm{O}$ caso em análise refere-se a José Inácio Pereira Derramado, médico e proprietário em Portel, de "origens honestas". Regista uma actividade política expressiva como deputado - 1823, 1826 e, posteriormente, entre 1837 a 1852 e Governador Civil de Beja e Évora (1837-1838), afirmando-se sem filiação partidária definida. Contava na altura da nomeação a Conselheiro 67 anos, tendo recusado a oferta de outras mercês honoríficas em nome dos ideais liberais e das origens plebeias de que se orgulhava, cf. Conceição Andrade Martins, "Derramado, José Inácio Pereira", Maria Filomena Mónica (dir.), Dicionário Biográfico Parlamentar, Lisboa, Instituto de Ciências Sociais/Assembleia da República, vol. II, 2005, pp. 33-35. Outros exemplos poderiam ser registados no sentido de evidenciar que a atitude de renúncia foi seguida por figuras de menor projecção pública relativamente ao empolamento atribuído à categoria dos notáveis liberais.

${ }^{(27)}$ Como valores dominantes são de realçar a ética do trabalho, a autonomia económica, a valorização da educação e o mérito individual retratados, analogamente, a partir da óptica de reformas concebidas como estruturantes do regime Constitucional Monárquico, designadamente a instrução pública, a questão da propriedade agrícola ou ainda a regulamentação jurídica da sociedade liberal, expressa no âmbito do processo da codificação civil. Matérias que receberam expressão nos investimentos intelectuais e políticos que perpassam as décadas de 30 e 60, cf. a síntese e bibliografia em Fátima Moura Ferreira, "Entre saberes: a centralidade do saber jurídico na consubstanciação da ordem liberal", Revista de História das Ideias, vol. 24, 2003, em especial pp. 178-191; Zília Osório de Castro, "Sociedade e Estado", Revista de História das Ideias, vol. 26, 2005, pp. 161-197; A. Manuel Hespanha, Guiando a mão invisivel, Coimbra, Almedina, 2005.

${ }^{(28)} \mathrm{Cf}$. no âmbito de uma perspectiva transversal sobre Oitocentos, entre outros, Jürgen Kocka (dir), Les bourgeoisies européennes au XIX's siècle, Paris, Belin, 1996; Jean-Pierre Chaline, Les Bourgeois de Rouen, une élite au XIX ${ }^{e}$ siècle, Presses de La Fondation Nationale des Sciences Politiques, 1982 ; Yannick Le Marec, Le temps des capacités, Paris, Belin, 2000; Maria Malatesta, I Professionist, Storia d'Italia, 
corrente das listas de agraciados com títulos e condecorações, sinal da ambivalência que perpassa o sentido atribuído a essas práticas, no curso do período conturbado de instauração do regime liberal.

Em sentido análogo, inscrevem-se ecos parlamentares produzidos, designadamente no âmbito do debate sobre direitos de mercês honoríficas, datado de 1845 , em que a questão da intensidade da nobilitação é abordada e o fenómeno considerado excessivo ${ }^{(29)}$. Já, então-se registam comentários irónicos sobre o título de Conselheiro, a pretexto da sua acelerada proliferação, o que testemunha a rápida visibilidade conquistada pelo novel símbolo, e, em simultâneo, a tendência para ser, a breve trecho, objecto de depreciação ${ }^{(30)}$.

Giulio Einaudi editore, 1996; Geoffrey Cocks, Konrad H. Jarausch (eds.), German Professions 1800-1950, Oxford, Oxford University Press, 1990

${ }^{(29)}$ Diário da Câmara dos Senhores Deputados, 21-2-1845, sessão nº 4, pp. 4-11, www.ar.pt. Aquando da discussão do citado projecto delei, queestá na base da lei de 26-3-1845, alguns dos deputados intervenientes, designadamente os proponentes (José Bernardo da Silva Cabral; Costa Simas, Oliveira Borges e J. R. Costa Cabral), contestaram o pensamento da pauta regulamentar de direitos de mercês de 1836 por fixar "direitos proibitivos" (Silva Ferrão). Em contraponto, sublinham o desígnio da proposta em análise, tendente a alargar as fontes de receita pública, mediante o concurso daqueles que voluntariamente pretendam ser agraciados com mercês honoríficas. Em análogo sentido, sustenta-se o estabelecimento de direitos módicos em relação ao título de conselho e às condecorações - "o ideal seria não ter lugar o pagamento " - uma vez que, por regra, tais graças correspondem a uma "remuneração do Estado", por serviços e merecimentos (Moura Coutinho).

${ }^{(30)}$ Registem-se algumas ilustrações desses comentários que versam sobre as diferentes categorias de condições honoríficas (nobilitados, conselheiros e condecorados): "não aceitaria o título de barão, nem carta de conselho, nem de visconde ainda que se empenhasse todo o mundo. Quando chegar a minha vez, o título de visconde há de estar tão por baixo que terei por força de principiar por conde. Isto vai indo de tal maneira, que a carta de conselho está como uma aldeia elevada à categoria de vila ou cidade. Moçamedes teve a sua carta de conselho foi elevada antes de ontem à categoria de vila (riso)" (comentário de António da Cunha Sotomaior no âmbito do debate sobre o projecto de reforma dos direitos de mercês). E, ainda, de análogo teor "Os morgados terão comenda e carta de conselho (riso) porque me parece que fica então bem o sistema", no quadro da apresentação de dois projectos de lei sobre a extinção de vínculos. In respectivamente, Diário da Câmara dos Senhores Deputados, de 19-04-1855, sessão $\mathrm{n}^{\circ} 3$, p. 171 e de 25-04-1845, sessão n ${ }^{\circ} 88$, p. 282. 
A começar pela equiparação forçada em relação aos títulos nobiliárquicos, dada a distância simbólica e material que os separa, ainda que partes integrantes, em termos de enquadramento legal, do universo honorífico, que marca uma parte substantiva da trajectória da sociedade constitucional. É certo que o fenómeno da nobilitação denota um maior encrustamento aos símbolos sociais da velha aristocracia, evidenciando as fortes resistências à adopção dớ valores tidos por próprios do individualismo liberal, parcamente interiorizados pela (ena) sociedade de então ${ }^{(31)}$. Mas, ao mesmo tempo, não deixa de constituir uma manifestação do poder económico dos recém titulares (tendência que irá revestir expressão acentuada no curso da segunda metade de Oitocentos, em face do perfil dos nobilitados oriundos das fracções da burguesia comercial), atendendo aos "direitos proibitivos" que regulam a respectiva condição ${ }^{(32)}$. Dimensão que, a seu modo, não deixaria de condicionar as observações sarcásticas e jocosas lançadas a respeito do ímpeto nobiliárquico, não obstante a crítica ter por base o esvaziamento

${ }^{(31)}$ Sobre a perda do poder político e social da nobreza tradicional ver Nuno Gonçalo Monteiro "O endividamento aristocrático (1750-1832): alguns aspectos", Análise Social, vol. XXVII (116-117), 1992, pp. 263-283; Maria Alexandra Lousada, "D. Pedro ou D. Miguel? As opçōes políticas da nobreza titulada portuguesa", Penélope. Fazer e desfazer História, $\mathrm{n}^{\circ}$ 4, 1989, pp. 82-111; Luís Espinha da Silveira, "Revolução liberal e pariato", Análise Social, vol. XXVII (116-117), 1992, pp. 329353; Maria Filomena Mónica, "A lenta morte da Câmara dos Pares (1878-1895)", Análise Social, vol. XXIX (125-126), 1994, pp. 121-152.

(32) É notória a distância dos direitos de mercês. Tomando por referência o imposto aplicado ao título de conselho por remuneração de serviços fixado em $100 \$ 000$ réis (dec. 31-12-1836), a disparidadeem relaçãoaos nobiliárquicos traduz-se, de acordo com a respectiva hierarquia, duque, marquês, conde, visconde e barão, em montantes superiores a 12, 8, 6, 3 e 4 vezes, agravada na circunstância de o título ser de juro e herdade. (A aparente incongruência dos valores referentes aos graus de visconde e de barão explica-se pelo facto de caso a condecoração incidir num escalão superior a barão a lei determina o pagamento suplementar dos direitos de mercê correspondentes à categoria imediatamente inferior). Sobre o perfil sócio-económico dos titulares nobilitados ver A. H. Oliveira Marques, História de Portugal, das Revoluções Liberais aos nossos dias, Lisboa, Palas Editora, $2^{\text {a }}$ ed. 1981, p. 119 ss. e José-Augusto França, ob. cit., pp. 260 ss. Intensidade da nobilitaçāo sob o Constitucionalismo: 1821-1850: 190 concessões; 1851-1890: 661 concessões (valores que contemplam a presença de estrangeiros e brasileiros ) A. H. Oliveira Marques, ob. cit., p. 119 ss. 
do símbolo, convertido em mero ornamento ostentatório - pese embora a duplicidade, potencialmente implícita, ao enunciado irónico, não raro traduzir o desejo inconfessado de ser titular, posição que encontra em Almeida Garrett um representante exemplar ${ }^{(33)}$.

Em contraponto, o título de Conselheiro tende a afirmar-se como símbolo próprio da sociedade dos novos tempos, ao usufruir da dignidade e da excelência adstrita, inicialmente, aos notáveis do regime, titulares por inerência de condição ou do cargo público desempenhado.

Daí a relevância da distinção legal que preside à nomeação de Conselheiro por "inerência de condição ou de cargo público" ou por "desígnio ministerial", sendo a graça outorgada como meio de remunerar serviços públicos e/ou qualidades pessoais e cívicas ${ }^{(34)}$.

Ser Conselheiro por inerência de condição ou de cargo público corresponde a uma distinção, sancionada por lei, fundada na tradição e nas novas

${ }^{(33)}$ Sublinhe-se que mesmo no interior das fracções ilustradas, correntemente, o valor da tradição aliado ao prestígio social jogava mais forte que a suposta fidelidade aos princípios levaria a admitir, dado o valor distintivo que, até cerca da década de 70, os títulos honoríficos conservaram, tomando como referência o declínio dos nobilitados no seio da elite política da Regeneração, patenteado por Tavares de Almeida. $O$ que não equivale a afirmar a quebra generalizada desse sentimento no interior das fracções que integram as classes médias. O comportamento de João da Silva Carvalho (1829-1880), oficial e par do reino, é a este respeito elucidativo, ao aceitar, em memória de seu pai (que por duas vezes recusara ser agraciado conde em nome dos ideais vintistas e das suas origens), o título de visconde Carvalho da Silva, em duas vidas (dec. de 13-12-1865), cf. António Viana, José da Silva Carvalho e o seu Tempo, vol. I, Lisboa, Imprensa Nacional, 1891, p. 5.

${ }^{(34)}$ Distinção formal (com tradução em termos de isenção de direitos de mercê) que apenas tenderá a revestir visibilidade e significado social, a partir de meados dos anos 80 e 90, momento a partir do qual se multiplicam os ecos de protesto parlamentares, acerca da exigência do pagamento de direitos sobre o título inerente ao cargo público a exercer, no âmbito da progressão na carreira ou pelo desempenho de funções ministeriais, acompanhada por atitudes de renúncia formal à sua concessão (cf. Diário da Câmara dos Senhores Deputados, nomeadamente, 20-03-1880, sessão $n^{\circ}$ 54, p. 1039; 6-06-1893, sessão $n^{\circ} 43$, p. 12; 6-06-1893, sessão $\mathrm{n}^{\circ} 43$, p. 12; 23-02-1899, p. 11; 19-07-1899; sessão ${ }^{\circ} 117$, p. 24; 23-02-1902, sessão $n^{\circ} 23$, p.1-28. O número de renúncias formais foi 33 , entre os anos 50 e a primeira década de 900, "Assentamento Geral das Pessoas Agraciadas com o titulo de Conselho, ...".). Sintoma marcante da quebra de prestígio aliada ao título entre o segmento médio alto da classe média. 
circunstâncias abertas pela implementação paulatina da ordem estatal liberal, símbolo distintivo da pertença ao reduzido universo das elites políticas e administrativas da Monarquia Constitucional ${ }^{(35)}$.

Daí que, nos primórdios do regime, a inerência se encontre adstrita a apenas algumas categorias emblemáticas: aos grandes do Reino-nobres com qualidade de grandeza e pares do reino, equiparados aos primeiros na sequência da reabertura da respectiva Câmara (dec. 28-9-1835) -, aos ministros, a fraç̧ões restritas do funcionalismo público superior - altos dignitários da magistratura judicial; governadores militares das províncias ultramarinas ${ }^{(36)}$; lente de prima, decano e director de qualquer das Faculdades da Universidade de Coimbra ${ }^{(37)}$; a novos lugares criados, filiados nas estruturas administrativa e militar que, sob a instauração da ordem liberal, são reputados de distinção correlata ${ }^{(38)}$; e a um leque diminuto de cargos dignificados por magnificência régia ${ }^{(39)}$.

O recorte sumário do universo dos notáveis do regime, consagrados com o título de Conselheiro, denota a exiguidade do traçado da máquina política e administrativa que tenderá a alargar-se, no âmbito da modernização das estruturas burocráticas, empreendida, sobretudo, a partir da Regeneração, em especial, no quạdro das reformas orgânicas lançadas entre os finais dos anos 50 e os anos 60 , e ulteriores ordenamentos reguladores do funcionalismo público (promulgados entre os anos $80 \mathrm{e}$ 90). O impacto dessas reformas evidenciar-se-á no aumento ainda que

(35) Ver Pedro Tavares de Almeida, A Construção do Estado Liberal, Elite Politica e Burocracia na 'Regeneração' (1851-1890), UNL/Faculdade de Ciências Sociais e Humanas, 1995, 2 vol., pp. 251-259.

${ }^{(36)}$ Alv. 24-4-1793; dec. de 7-12-1836 e lei de 26-3-1845.

${ }^{(37)} \mathrm{Na}$ condição de o exercício do lugar ter ocorrido, no mínimo, há oito anos (C.R. 27-10-1824).

(38) Prefeito de Província (art. $32^{\circ}$ do dec. de 16-5-1832); juiz relator do Supremo Conselho de Justiça Militar e juiz ajudante do mesmo cargo (dec. de 9-12-1836); Director Geral da Câmara dos Deputados (lei de 9-4-1838); Vogal efectivo da secção da Marinha do Supremo Conselho de Justiça Militar (dec. 8-8-1840); Presidente da Relação de Luanda (art. 31 NRJ, dec. 21-5-1841) Secretário do Conselho de Estado (Regimento com força de lei de 9-1-1850) - categorias recenseadas, de acordo com o "Assentamento Geral das Pessoas Agraciadas com o titulo de Conselho, 1832-1910", ANTT, MR Liv. 927.

${ }^{(39)}$ Designadamente, Prior da Insigne e Real Colegiada de Nossa Senhora da Oliveira, alv. de 4-4-1795; Porteiro da Real Câmara; alv. 17-12-1808. 
diminuto, de cargos públicos com Carta de Conselho por inerência, correspondentes aos lugares de topo das respectivas carreiras, ou a lugares de organismos dotados de forte prestígio ${ }^{(40)}$, reflexo do pendor selectivo que a concessão conserva, actuando para a preservação das distâncias simbólicas entre segmentos do funcionalismo do passado ${ }^{(41)}$.

Mas, contrariamente ao que faria supor o espírito da lei, a via de acesso dominante ao universo dos Conselheiros consiste na concessão do título por desígnio ministerial, em remuneração de serviços públicos distintos ou de qualidades pessoais relevantes, que contempla mais de $60 \%$ do universo dos agraciados durante o Constitucionalismo ${ }^{(42)}$.

A tendência afirma-se precocemente, na década de 40 . A partir de então, tende a generalizar-se a remuneração por bons serviços desempenhados nas diversas carreiras do funcionalismo público superior e, em alguns casos, médio alto, nas vertentes civil, militar e eclesiástica, de acordo com o motivo que justifica a concessão da mercê. É certo que o leque das motivações se apresenta mais amplo. Frequentemente, é invocada a longevidade dos serviços. Mais raras vezes, é referida uma missão particular de natureza diplomática, financeira ou régia. O desempenho de comissões públicas ou de cargos públicos figura, ainda que em termos esparsos. Igualmente contemplado apresenta-se o exercício de funções políticas de recorte distrital (e.g o governador civil, uma das presenças mais constantes) e, em menor número, de âmbito nacional (deputado). Presente, ainda que de um modo mais lateral, estão os serviços prestados aos monarcas em ocasiões particulares: por ocasião do "consórcio régio" (1862) ou no âmbito de visitas reais (1852, $1901,1908)^{(43)}$.

${ }^{(40)}$ Alguns exemplos: directores-gerais dos ministérios, vogais do Tribunal de Contas; vogal do Tribunal Administrativo; os comissários régios das empresas estatais, em fase mais tardia.

${ }^{(41)}$ Disso é exemplo a distinção usufruída exclusivamente pelos professores decanos da Universidade de Coimbra.

(42) Com rigor $62,5 \% 1019$ em 1623.

${ }^{(43)} \mathrm{O}$ padrão sócio-profissional da graça por remuneração de serviços é largamente análogo ao da concessão por inerência, com a diferença que, neste último caso, excluindo os ministros, os pares e os titulares com grándeza, é mencionado exclusivamente o cargo que legitima a concessão, acompanhado da respectiva referência legal. Mas a incidência da nomeação por inerência de cargo reveste-se pouco expressiva, ao longo do Constitucionalismo, na ordem 
A rápida visibilidade conquistada pelo título de Conselheiro, nos alvores do Constitucionalismo, encontra as suas raízes, justamente, numa prática que se reconverteu em norma, justificando a crescente proliferação de agraciados no curso de Oitocentos ${ }^{(44)}$.

Certamente, as razões de prestígio social associadas ao título terão exercido uma influência considerável na sua contínua propagação, sobretudo tendo presente a tradicional valorização dos símbolos honoríficos observada na sociedade portuguesa. E, contrariando os ecos depreciativos que rapidamente se propagaram entre os observadores atentos e críticos das reputadas "vaidades sociais" - como dizia José Estevão: "Nunca pude compreender o que é uma Carta de Conselho num homem que não pode dar conselhos nem conseguir que ninguém lhos tome" $(1845)^{(45)}$-, o título conservou relevância social até cerca dos anos 90 , ainda que, em termos práticos, se traduzisse apenas no direito ao tratamento de "Excelência", intervindo, ainda, nas cerimónias oficiais em termos protocolares.

Acresce uma razão certamente mais poderosa. Em termos da realidade social portuguesa, o título potenciava a qualidade, também ela distintiva e prestigiante, de pertença aos segmentos superior e, em menor escala, médio alto do funcionalismo público, num país debilmente modernizado, em que as oportunidades de emprego exteriores ao Estado escasseavam, possibilitando alimentar trajectórias de mobilidade ascendente ou de reprodução social, sobretudo quando suportadas pela certificação de estudos universitários ou superiores.

dos $8 \%$ na época correspondente à instauração do regime liberal (1834-1849) e nas décadas terminais da Monarquia, 1890-1910 (respectivamente, 8,3\% e 8,1\%), revestindo valores inferiores, nos sub-períodos compreendidos pela Regeneração (1850-1869; 1870-1889).

(44) Dai que o número de contemplados não tenha cessado de crescer, pese embora a oscilação registada entre os anos 70 e 90 , logo recuperada, de acordo com a distribuição que se apresenta: 348 entre 1834-1849; 410 entre 1850-1869; 323 entre 1870-1889; e 542 entre 1890-1910.

${ }^{(45)}$ Observação jocosa de José Estêvão, lançada, curiosamente, no âmbito de um debate sobre as condiçōes de ingresso dos alunos na Escola do Exército, o que invariavelmente provocava o accionamento das rivalidades entre a Escola Politécnica e a Universidade de Coimbra. Diário da Câmara dos Senhores Deputados, 3-02-1845, sessão n $^{\circ} 27$, p. 17. 
Mas importará não negligenciar as contrapartidas estatais decorrentes da política remuneratória, em termos da concessão de mercês honoríficas. No que concerne ao título de Conselheiro, esta repercutiu-se, em particular, no reforço da fidelização política ao regime, intervindo, à sua escala, como canal de irradiação da mística estatal. Testemunham-no o número das nomeações de governadores civis ao longo do Constitucionalismoe, em particular, os requerimentos dos próprios que solicitavam a graça invocando o exemplo seguido, que, entretanto, se convertera em norma. Ou, ainda, a alegação do forte impacto que o título exercia entre a população da província, contribuindo, nas palavras de um requerente (no caso em apreço, um oficial militar), para reforçar a autoridade exigida ao desempenho do lugar.

A preponderância do funcionalismo público civil no universo dos agraciados não deve, porém, escamotear os propósitos de promoção das qualidades profissionais exigidas aos seus quadros superiores - traduzidas através da fórmula então corrente "zelo, inteligência e probidade"-, intervindo, igualmente, como meio de premiar aqueles que se distinguiam. Por outro lado, o título agia como um estímulo à qualificação do desempenho dos seus pares, tal como o evidenciam os requerimentos remetidos pelas chefias administrativas ou judiciais, designadamente, aos titulares das pastas ministeriais da especialidade. $\mathrm{E}$, na mesma linha, remunerando serviços suplementares (como lembravam os ecos de debates parlamentares realizados no âmbito de comissões públicas ou de missões particulares) dada as indisponibilidades financeiras estatais.

\section{A reconversão da prática em norma}

A prática régia de agraciar encontra, na conjuntura política-militar que atravessou as décadas da instauração definitiva do liberalismo (1834-1849) uma época propícia à remuneração de serviços públicos. E esta, certamente, teve o seu pretexto, designadamente, nas alusões diversas ao envolvimento na "causa de legitimação da rainha", nos serviços militares, financeiros, administrativos, nos padecimentos sofridos, ou, ainda, nos momentos posteriores que marcam o ciclo de instabilidade até à Regeneração. Todavia, o motivo maior que justifica a propagação quase ininterrupta do título durante o Constitucionalismo (excluindo 
a oscilação registada entre 1870-1889) é a conversão da prática da remuneração em norma, quando justificada. Com efeito, precocemente, ao longo dos anos 40, os requerimentos dos próprios, solicitando a graça, alegam, em paralelo à qualidade e à longevidade dós serviços, o "exemplo dos colegas" - oficiais administrativos das repartições, juízes da Relação, oficiais da marinha e do exército. Por vezes, é referida a circunstância insólita de se ser o único na categoria a não dispor da distinção. Em outros casos, alude-se à antiguidade no lugar e ao facto de pares mais modernos ostentarem o título, permitindo alimentar interpretações infundadas sobre a eventual desqualificação do próprio. As alegações enunciadas não deixam de encontrar eco nas solicitações das entidades de chefia. Mas, releve-se que a invocação da fórmula "a exemplo de" encontra o seu fundamento na tradição da prática régia de agraciar, conservada pelo novel regime, fundamentando a aspiração e a expectativa legítima do requerente adquirir análoga distinção(46).

Daí a expressão diminuta que a inerência ao título tende a revestir, de forma pronunciada durante as décadas de Regeneração, uma vez que, regra geral, se encontra adstrita aos lugares de topo das carreiras em que tem lugar. Assim, ser Conselheiro tende a generalizar-se entre o segmento superior do funcionalismo técnico especializado, nomeadamente entre a magistratura judicial superior ou lugares do Ministério Público equivalentes (quando, por.inerência, só teria lugar a partir do cargo

(46) Constatamos apenas um único caso de invocação explícita da tradição na extensa série de processos de decretos de Cartas de Conselho do Ministério do Reino compulsada. Traduz-se na alegação ao costume de agraciar os filhos dos desembargadores com mercês várias, entretanto, caídas em desuso, que caminha a par com a alegação dos serviços prestados pelo próprio, meio de consolidar o fundamento da solicitação da carta de conselho e, em particular, a isenção dos respectivos direitos. O parecer do Fiscal das Mercês, confirmado por opiniāo análoga do Procưrador Geral da Coroa, não é menos esclarecedor da legitimidade da alegação ao costume antigo, ao considerar que o pedido do requerente fica aquém das expectativas a que poderia legitimamente aspirar, em face dos seus serviços, na qualidade de oficial maior da Secretaria do Estado dos Negócios do Reino e da longevidade dos praticados por seu pai, magistrado judicial, durante quarenta anos, "dos quais não obteve ainda a totalidade das mercês que por prática lhe pertenciam" ANTT-Ministério do Reino - Série Decretos, mç. 1254 e $1255 \mathrm{n}^{\circ}$ prov., Processo de António José Dique da Fonseca, decreto de título de conselho 7-12-1843. 
de Presidente da Relação ou do lugar de juiz do Supremo Tribunal de Justiça e de Procurador Geral da Coroa), ou entre os professores do Ensino Superior (em que a distinção se encontra ausente da respectiva carreira). E as ilustrações poderiam multiplicar-se a outros segmentos do funcionalismo público. Importa registar, em paralelo, os requerimentos dos próprios, em que são invocados, a par dos serviços pessoais, os exercidos, no quadro de quatro gerações, designadamente na carreira militar.

Outro canal mais tardio que contribui, certamente, para a generalização da prática (mas sobre o qual não é possível apresentar qualquer estimativa de pendor quantificativo), consiste nas redes de sociabilidades políticas e partidárias. O informalismo do pedido é parcamente justificado, aludindo-se à expectativa e ao interesse do pretendente, tradução do prestígio que o título encerra. Aí, a alusão ao conhecimento pessoal do pretendente caminha a par com a referência breve sobre a categoria professional, suportada, em termos recorrentes, com uma nota de registo do próprio, descritiva dos lugares ou missões exercidas, desprovidas, porém, de carácter extraordinário. Igualmente intervêm as redes partidárias regionais, através de pedidos expressos de nomeação de figuras pelo seu empenho no combate eleitoral, ou, nas proximidades do fim do século, pelo prestígio social e reconhecimento público junto da comunidade. Meio de legitimar, à sua escala, o pedido, numa época em que o título de Conselheiro atinge valores exponenciais?

\section{A dignificação dos segmentos superiores do funcionalismo público}

A evidência queiroseana, tal como o tínhamos sugerido, apresenta ressonância empírica. Contudo ela deve ser precisada. É certo que, entre os três grupos que integram o universo dos Conselheiros (funcionalismo público, nas vertentes civil, militar e eclesiástica; cargos políticos e sociedade civil), o segmento preponderante é o primeiro ${ }^{(47)}$.

A sua presença é esmagadora no conjunto do Constitucionalismo, apresentando um valor médio de $61 \%$ (985), segundo um intervalo que

${ }^{(47)} \mathrm{O}$ critério de referência adoptado consistiu no motivo da concessão e não na profissão, pois neste caso o fenómeno seria ainda mais expressivo. 
regista um máximo de $67,5 \%$ (277) e um mínimo de $53,5 \%$ (290), atinentes, respectivamente, às décadas inaugurais da Regeneração e ao desfecho da Monarquia (1890-1910). Importa, porém, esclarecer as disparidades notórias que encontramos entre os seus três pilares.

A presença do funcionalismo eclesiástico afigura-se residual, contemplando, na fase inaugural do regime, de forma preponderante, os altos dignitários da Igreja, em especial os bispos (comassento por inerência na Câmara dos Pares), tendendo a incorporar outros de qualidade distintiva (designadamente cónegos) e, na fase terminal da Monarquia, representantes estatutariamente inferiores ${ }^{(48)}$.

Os militares, por seu turno, confinados aos segmentos superior e médio do alto funcionalismo, denotam uma presença desigual e oscilante, ao longo do Constitucionalismo, no sub-universo conselheiral em análise. A sua expressão mais relevante encontra o seu fundamento no papel activo que desempenharam no decurso da conjuntura de acentuada instabilidade política-militar que existiu até à Regeneração, traduzida numa política remuneratória que contemplava, expressivamente, os bons serviços na ordem dos $25 \%$ em relação ao total dos agraciados no $1^{\circ}$ coorte em análise. Esta tendeu a regredir, ao longo da segunda metade de Oitocentos, não obstante os lugares de primeiro plano, afectos à governação das províncias ultramarinas e aos conselhos militares, que usufruíam do título distintivo por inerência.

Por último, o funcionalismo civil configura-se como o mais representativo do sub-universo conselheiral em análise, e, em simultâneo como o segmento maior entre o conjunto dos agraciados, nas décadas que compreendem a Regeneração, tendo atingido, nesta etapa, 50\% das nomeações de conselho. Integra, porém, fracções marcadamente diferenciadas, atendendo à especificidade funcional que as marca, correspondendo, por excelência, aos quadros superiores do Estado. De entre elas, a magistratura judicial e o professorado superior salientam-se pelo perfil marcadamente autonomizado que espelham, e que decorre do pendor especializado das suas funções e da precoce estruturação de carreiras que evidenciam. Em contraponto, a terceira fracção corporiza

${ }^{(48)}$ A análise da estrutura funcional e hierárquica do funcionalismo tem por referente o modelo de estratificação social definido por Pedro Tavares de Almeida para a respectiva população, adaptado ao universo em estudo, cf. A Construção do Estado Liberal, Elite Política e Burocracia ..., pp. 376-378 (explanado pp. 379-394). 
o funcionalismo administrativo e compreende as funções que denotam um pendor mais marcadamente administrativo, desenvolvidas, de forma preferencial, no quadro da administração central, bem com um pólo, de recorte menor, afecto a actividades técnico-administrativas (engenheiros e grupos afins). A sua afirmação tem lugar, por excelência, no âmbito da política dos melhoramentos materiais, desenvolvida a partir dos anos 50, com tradução no movimento de modernização das estruturas burocráticas e no aumento significativo dos seus efectivos. E que recebe expressão, em termos concomitantes, na ostentação da maior parcela de titulares, durante as décadas compreendidas pela Regeneração, com valores, sensivelmente análogos, na ordem dos $25 \%$.

Intencionalmente, excluímos da contabilização do funcionalismo público o governador civil pelo carácter amovível do cargo, que se traduz na ausência de uma carreira formalizada em contraste com o demais funcionalismo. As suas funções eram, em todo o caso, reputadas como pertencentes à carreira administrativa, na qualidade de representante do poder central, à escala distrital, actuando como elemento de ligação entre o centro e a periferia. Contrariamente aos ministros, que figuram ao longo do Constitucionalismo, como Conselheiros por inerência do cargo, tradução da respeitabilidade e da excelência adstrita ao lugar, a presença do governador civil, ainda que constante e representativa, decorre da remuneração do serviço público, acabando a prática da nomeação por se generalizar, precocemente, constituindo $11 \%$ (177) do universo dos agraciados. Nestas circunstâncias, e atendendo à relevância das suas competências político-administrativas e, sobretudo, ao papel desempenhado na concretitude do regime à escala regional, dir-se-ia que ele constitui a versão política do Conselheiro, indo ao encontro das imagens coevas, designadamente literárias, sobre o excesso do funcionalismo administrativo e da debilidade da figura do governador civil. Afinal, os dois (novos) braços direitos do Estado Constitucional e, a seu modo, na perspectiva dos excluídos, os grandes usufrutuários. Mas, contrariamente às interpretações veiculadas face à visibilidade do fenómeno aos olhares contemporâneos, este, longe de trair qualquer 
especificidade nacional, terá correspondido a uma tendência inerente ao processo de modernização das estruturas estatais ${ }^{(49)}$.

O grande ausente é a sociedade civil, embora registe uma progressão contínua, ao longo do Constitucionalismo, pois partiu de uma base ínfima de $3 \%$ e atingiu um valor expressivo de cerca de $14 \%$, nas décadas terminais do regime. Mas o seu aparente reconhecimento - que reveste visibilidade através da remuneração dos serviços de entidades associativas, comportamentos beneméritos e dos merecimentos pessoais de algumas individualidades - trai, analogamente, a desvalorização a que o título de Conselheiro é sujeito a partir dos anos 90 . São disso testemunho as categorias laterais que tendem a emergir em termos mais expressivos (os presidentes de câmaras e outros cargos municipais; as personalidades de âmbito local, entre outros), o aumento do número dos agraciados que caminha a par com as renúncias formais, designadamente de quadros superiores do funcionalismo que rejeitam a remuneração porque não inerente.

O perfil sociológico do universo dos Conselheiros, nesta época, contrasta marcadamente com o recorte aristocratizante que o regime procurou, a seu modo, preservar nos primórdios liberais, reflectidos na presença de funcionários da Casa Real e dos titulares nobiliárquicos com grandeza, por inerência nomeados Conselheiros - manifestação do hibridismo social que perpassou a época da instauração definitiva do liberalismo. Em contraponto, precocemente, o Conselheiro tende a prefigurar o representante da novel sociedade. Assim o indicia a expressão diminuta dos titulares nobiliárquicos entre os seus pares $(10,8 \%)$ - na sua maioria pertencentes aos graus inferiores da respectiva hierarquia $(58,3 \%)$ e agraciados posteriormente à Carta de Conselho--, a significativa expressão do seu envolvimento político $(42,5 \%)$ - maioritariamente na qualidade de deputado - bem como o largo contingente de diplomados, reflexo, em suma, dos símbolos das novas elites, pertencentes à classe média. E que se exprime, a seu modo, numa cultura que elege o trabalho,

${ }^{(49)}$ Cf. Pedro Tavares de Almeida, ob. cit., p. 275. Por contraponto, retenha-se o contorno fluído da elite política do Constitucionalismo no universo conselheiral. Os pares do reino surgem apenas nomeados até 1854, mas, recorde-se, na circunstância de terem sido equiparados aos titulares com grandeza. O número de deputados agraciados, posteriormente, pelo desempenho de cargos políticos é notoriamente escasso (23 casos), pois a graça decorria, amplamente, da pertença ao funcionalismo público superior. 
a dedicação ao Estado, o respeito pela autoridade e a sobriedade como valores principais do comportamento socialmente prestigiante, uma das vertentes que caracteriza a complexa afirmação da identidade social da classe média.

"Era apenas conselheiro. E porquê? Porque tinha 33 annos de Universidade. Possuía essa mercê de direito, dizia-lo ele, por vezes, quando se lhe offerecia outras: '- Não, há apenas uma com que me honro; e se tiver saúde e vida hei de tê-la: é a carta de conselho, por direito de trabalho, inerente ao meu cargo oficial.' - sentido que encontra a sua plena expressão na abnegação com que serviu o seu partido (progressista) e o país, na modéstia que caracterizava a sua vida e que marcou o seu enterro, desprovido de honras oficiais, nas palavras do deputado Oliveira Matos, aquando do falecimento do Professor da Faculdade de Direito, Pedro Castelo Branco"(50).

${ }^{(50)}$ Actas da Câmara dos Senhores Deputados, sessão n ${ }^{\circ} 1,20$ Janeiro 1903, pp. 4-5 